\title{
SPECIES DISTINCTNESS OF HAUFFENIA MICHLERI (KUŠČER, 1932) (CAENOGASTROPODA: TRUNCATELLOIDEA: HYDROBIIDAE)
}

\author{
ANDRZEJ FALNIOWSKI, MAGDALENA SZAROWSKA
}

\begin{abstract}
Department of Malacology, Institute of Zoology, Jagiellonian University, Gronostajowa 9, 30-387 Cracow, Poland (e-mail: andrzej.falniowski@uj.edu.pl)

ABSTRACT: Hauffenia michleri (Kuščer, 1932) was described from Močilnik spring in Slovenia. Later it was regarded as conspecific with $H$. tellinii Pollonera, 1898, since no differences in the soft parts morphology and anatomy were found. In the present paper, applying molecular markers (mitochondrial cytochrome oxidase subunit I and nuclear $18 \mathrm{~S}$ ribosomal RNA partial gene sequences), the genetic differences typical of congeneric distinct species (p distances 0.067, and 0.005, respectively) were found, proving the species distinctness of $H$. michleri.
\end{abstract}

KEY WORDS: mtDNA, COI, 18SrRNA, p-distance, Slovenia

\section{INTRODUCTION}

Močilnik, the main source of the Ljubljanica River, Slovenia is inhabited by interesting representatives of the Hydrobiidae (BOLE 1967, 1985, RADOMAN 1983). KUŠČER (1932) described a minute valvatiform hydrobiid snail Hauffenia michleri (Fig. 1) from this locality. Later, considering the shell and anatomy, BODON et al. (2001) synonymised H. michleri (Kuščer, 1932) with H. tellinii Pollonera, 1898 from
Italy. However, in the truncatelloidean gastropods, morphology alone is often insufficient for species delimitation (e.g. SZAROWSKA \& FALNIOWSKI 2008). Thus, we have tried to evaluate the species distinctness of $H$. michleri applying molecular markers (mitochondrial cytochrome oxidase subunit I and nuclear $18 \mathrm{~S}$ ribosomal RNA partial gene sequences).

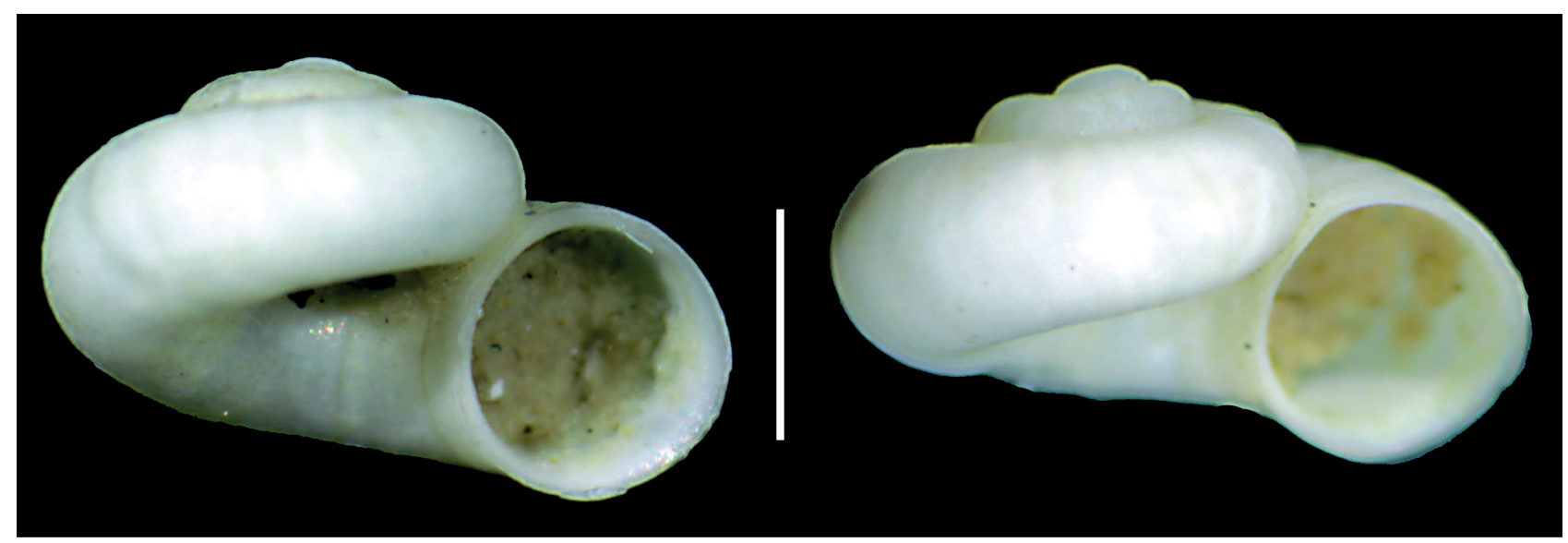

Fig. 1. Shells of Hauffenia michleri (Kuščer, 1932) from Močilnik spring. Bar equals 0.5 mm 


\section{MATERIAL AND METHODS}

Five live specimens of Hauffenia michleri were collected using a sieve (two meshes per $\mathrm{mm}$ ), from Močilnik, the type locality of this species, the huge spring of the Ljubljanica River $\left(45^{\circ} 57^{\prime} 15^{\prime \prime} \mathrm{N}\right.$, $14^{\circ} 17^{\prime} 33^{\prime \prime} \mathrm{E}, 313 \mathrm{~m}$ a.s.l.). The snails were washed twice in $80 \%$ ethanol and left to stand in it for around 12 hours. Then the ethanol was changed twice more within 24 hours and finally, after a few days, the $80 \%$ solution was replaced with a $96 \%$ one, in which the samples were stored at $-20^{\circ} \mathrm{C}$. The shells were photographed with a CANON EOS 50D digital camera attached to NIKON SMZ-18 stereoscopic microscope with the dark field.

DNA was extracted from foot tissue of two specimens. The tissue was hydrated in TE buffer $(3 \times 10$ min. $)$; then total genomic DNA was extracted with the SHERLOCK extracting kit (A\&A Biotechnology), and the final product was dissolved in $20 \mu \mathrm{l}$ TE buffer. The PCR reaction was performed with the following primers: LCO1490 (5'-GGTCA ACAAATCATAAAGATATTGG-3') (FOLMER et al. 1994) and COR722b (5'-TAAACTTCAGGGTGACCAAAAAATYA-3') (WILKE \& DAVIS 2000) for the mitochondrial cytochrome oxidase subunit I (COI) gene and SWAM18SF1 (5'-GAATGGCTCATTAAATCAGTCGAGGTTCCTTAGATGATCCAAATC-3'), and SWAM18SR1
(5'-ATCCTCGTTAAAGGGTTTAAATTAAAGTGGTGTACTCATTCCAATTACGGAGC-3') for the nuclear 18S ribosomal RNA (18S) gene (ATTWOOD et al. 2003). The PCR conditions were as follows: COI - initial denaturation step of $4 \mathrm{~min}$ at $94^{\circ} \mathrm{C}$, followed by 35 cycles of $1 \mathrm{~min}$ at $94^{\circ} \mathrm{C}, 1 \mathrm{~min}$ at $55^{\circ} \mathrm{C}, 2 \mathrm{~min}$ at $72^{\circ} \mathrm{C}$, and a final extension of $4 \mathrm{~min}$ at $72^{\circ} \mathrm{C} ; 18 \mathrm{~S}$ - initial denaturation step of $4 \mathrm{~min}$ at $94^{\circ} \mathrm{C}$, followed by 40 cycles of $45 \mathrm{~s}$ at $94^{\circ} \mathrm{C}, 45 \mathrm{~s}$ at $51^{\circ} \mathrm{C}, 2 \mathrm{~min}$ at $72^{\circ} \mathrm{C}$ and, after all cycles were completed, an additional elongation step of $4 \mathrm{~min}$ at $72^{\circ} \mathrm{C}$ was performed. The total volume of each PCR reaction mixture was $50 \mu \mathrm{l}$. To check the quality of the PCR products 10 $\mu \mathrm{l}$ of the PCR product was ran on $1 \%$ agarose gel. The PCR products were purified using Clean-Up columns (A\&A Biotechnology) and were then amplified in both directions using BigDye Terminator v3.1 (Applied Biosystems), following the manufacturer's protocol and with the primers described above. The sequencing reaction products were purified using ExTerminator Columns (A\&A Biotechnology); DNA sequences then underwent electrophoresis on an ABI Prism sequencer. The COI sequences were aligned by eye using BioEdit 5.0.0 (HALL 1999); alignment for $18 \mathrm{~S}$ was performed using CLUSTALX 1.82 (THOMPSON et al. 1997), and p-distances computed with MEGA5.10 (TAMURA et al. 2011).

\section{RESULTS AND DISCUSSION}

Two sequences of nuclear 18S ribosomal RNA (18S) gene, 404 bp long (GenBank number KT236155), were identical, and two sequences of mitochondrial cytochrome oxidase subunit I (COI) gene, $641 \mathrm{bp}$ long (GenBank number KT236156) were identical as well. They were compared with the sequences of Hauffenia tellinii (Pollonera, 1898) (GenBank numbers AF367672, and AF367640: WILKE et al. 2001), collected at a spring near the Isonzo River near the dam of Sagrado, Friuli-Venetia-Julia, Gorizia, Italy. The p-distance for $18 \mathrm{~S}$ was 0.005 (two point mutations), and the p-distance for COI was 0.067 (43 substitutions). The two substitutions in $18 \mathrm{~S}$ are noteworthy, since there are often no differences in $18 \mathrm{~S}$ between closely related species. The distance calculated for $\mathrm{COI}$ between $H$. michleri and $H$. tellinii is typical - in the Truncatelloidea - of distinct species, belonging to the same genus (e.g. FALNIOWSKI et al. 2007, 2009, SZAROWSKA et al. 2007, FALNIOWSKI \& SZAROWSKA 2011). Thus, the species distinctness of $H$. michleri seems evident, and synonymisation intruduced by BODON et al. (2001) not justified.

Certainly, the genetic distances alone, especially calculated for a few short sequences only, may not always be decisive. There are some cases which need further explanation, for example morphologically distinct, sympatric taxa with slight differences in COI sequences in Bythinella (HAASE et al. 2007, our observation on the Polish Bythinella) on the one hand, and about $5 \%$ differences within the same nominal species of Bythinella (FEHÉR et al. 2013) on the other. Morphological differences may not be reflected molecularly (WILKE \& FALNIOWSKI 2001), or molecularly distinct species may not be morphologically distinguishable (e.g. SZAROWSKA \& FALNIOWSKI 2014). Genetic data, however, may be the only key to discover cryptic species, the latter especially frequent among minute gastropods, whose morphology is simplified because of miniaturisation, and unified because of the necessary adaptation to live and reproduce in freshwater.

\section{ACKNOWLEDGEMENTS}

The study was supported by a grant from the National Science Centre (2012/05/B/NZ8/00407) to MAGDALENA SZAROWSKA. 


\section{REFERENCES}

AtTwood S. W., AmbU S., Meng X.-H., Upatham E. S., XU F.-S., SouthGate V. R. 2003. The phylogenetics of Triculine snails (Rissooidea: Pomatiopsidae) from South-East Asia and southern China: historical biogeography and the transmission of human schistosomiasis. J. Mollus. Stud. 69: 263-271. http://dx.doi. org/10.1093/mollus/69.3.263

Bodon M., MANGANElli G., GiUsti F. 2001. A survey of the European valvatiform hydrobiid genera, with special reference to Hauffenia Pollonera, 1898 (Gastropoda: Hydrobiidae). Malacologia 43: 103-215.

BOLE J. 1967. Taksonomska, ekološka i zoogeografska problematika družine Hydrobiidae (Gastropoda) iz porečja Ljubljanice. Razprave IV razr. SAZU 10: 73-108.

BOLE J. 1985. Podzemeljski vodni polži kažejo na razvoj porečja Ljubljanice. Proteus 48: 16-20.

FALNIOWSKI A., SZAROWSKA M. 2011. Radiation and phylogeography in a spring snail Bythinella (Mollusca: Gastropoda: Rissooidea) in continental Greece. Ann. Zool. Fenn. 48: 67-90. http://dx.doi org/10.5735/086.048.0201

FALNIOWSKI A., SZAROWSKA M., GRZMIL P. 2007. Daphniola Radoman, 1973 (Gastropoda: Hydrobiidae): shell biometry, mtDNA, and the Pliocene flooding. J. Nat. Hist. 41: 2301-2311. http://dx.doi. org/10.1080/00222930701630733

FALNIOWSKI A., SZAROWSKA M., SIRBU I. 2009. Bythinella Moquin-Tandon, 1856 (Gastropoda: Rissooidea: Bythinellidae) in Romania: species richness in a glacial refugium. J. Nat. Hist. 43: 2955-2973. http://dx.doi. org/10.1080/00222930903359636

FEHÉr Z., MAJOR A., KRÍZSIK V. 2013. Spatial pattern of intraspecific mitochondrial diversity in the Northern Carpathian endemic spring snail, Bythinella pannonica (Frauenfeld, 1865) (Gastropoda: Hydrobiidae). Org. Diver. Evol. 13: 569-581. http://dx.doi.org/10.1007/ s13127-013-0141-7

Folmer O., Black M, HoEH W., LutZ R. A., VRIJENHOEK R. C. 1994. DNA primers for amplification of mitochondrial cytochrome $\mathrm{c}$ oxidase subunit I from diverse metazoan invertebrates. Mol. Mar. Biol. Biotechnol. 3: 294-299.

HAASE M., WiLKE T., MiLDNER P. 2007. Identifying species of Bythinella (Caenogastropoda: Rissooidea): a plea for an integrative approach. Zootaxa 1563: 1-16.

HALL T. A. 1999. BioEdit: a user-friendly biological sequence alignment editor and analysis program for Windows 95/98/NT. Nucleic Acids Symp. Ser. 41: 9598.

KUŠČER L. 1932. Höhlen- und Quellenschneckenaus dem Flussgebiet der Ljubljanica. Arch. Moll. 64: 48-62.

RADOMAN P. 1983. Hydrobioidea a superfamily of Prosobranchia (Gastropoda). I Systematics. Serbian
Academy of Sciences and Arts, Monographs 547, Department of Sciences 57: 1-256.

SZAROWSKA M., FALNIOWSKI A. 2008. There is no philosopher's stone: coup de grace for the morphologybased systematics in the rissooidean gastropods? 5th Congress of the European Malacological Societies, Ponta Delgada: 28.

SZAROWSKA M., FALNIOWSKI A. 2014. Ventrosia mariti$m a$ (Milaschewitsch, 1916) and V. ventrosa (Montagu, 1803) in Greece: molecular data as a source of information about species ranges within the Hydrobiinae (Caenogastropoda: Truncatelloidea). Folia Malacol. 22: 61-67. http://dx.doi.org/10.12657/folmal.022.006

SZAROWSKA M., GRZMIL P., FALNIOWSKI A., SIRBU I. 2007. Grossuana codreanui (Grossu, 1946) and the phylogenetic relationships of the East Balkan genus Grossuana (Radoman, 1973) (Gastropoda: Rissooidea). Hydrobiologia 579: 379-391. http://dx. doi.org/10.1007/s10750-006-0530-4

Tamura K., Peterson D., Peterson N., Stecher G., NeI M., KuMAR S. 2011. MEGA5: Molecular evolutionary genetics analysis using maximum likelihood, evolutionary distance, and maximum parsimony method. Mol. Biol. Evol. 28: 2731-2739. http://dx.doi.org/10.1093/ molbev/msr121

Thompson J. D., Gibson T. J., Plewniak F., JeAnmougin F., HigGins D. G. 1997. The ClustalX windows interface: flexible strategies for multiple sequence alignment aided by quality analysis tools. Nucleic Acids Res. 24: 4876-4882. http://dx.doi.org/10.1093/nar/25.24.4876

WiLKE T., DAVIS G. M. 2000. Infraspecific mitochondrial sequence diversity in Hydrobia ulvae and Hydrobia ventrosa (Hydrobiidae: Rissoacea: Gastropoda): Do their different life histories affect biogeographic patterns and gene flow? Biol. J. Linn. Soc. 70: 89-105. http://dx.doi. org/10.1111/j.1095-8312.2000.tb00202.x

Wilke T., DAVIS G. M., FALNIOWSKI A., GiUSTI F., BODON M., SZAROWSKA M. 2001. Molecular systematics of Hydrobiidae (Gastropoda: Rissooidea): testing monophyly and phylogenetic relationships. Proc. Acad. Nat. Sci. Philadelphia 151: 1-21. http:// dx.doi.org/10.1635/0097-3157(2001)151 [0001:MSOHMG]2.0.CO;2

Wilke T., FALNIOWSKI A. 2001. The genus Adriohydrobia (Hydrobiidae: Gastropoda): polytypic species or polymorphic populations? J. Zool. Syst. Evol. Research 39: 227-234. http://dx.doi.org/10.1046/j.14390469.2001.00171.x

Received: April 7th, 2015

Revised: May 5th, 2015

Accepted: May 28th, 2015

Published on-line: July 8th, 2015 